\title{
BUFFER MANAGEMENT IN CONSTRUCTION - A NEW ZEALAND STUDY
}

\author{
M. Poshdar'1, V.A. Gonzalez ${ }^{2}$, and Kasiviswanathan B $^{3}$
}

\begin{abstract}
Buffers in the form of extra capacity, time, or inventory can help stabilizingconstruction workflow. From a lean construction perspective, however, buffers are recognized as waste. It presents a dichotomy in the use of buffers that calls for the establishment of a balance between the theoretical goals and the practical norms. This paper presents a study on the practical norms of buffer management in construction projects in New Zealand. Twelve semi-structured face-to-face interviews were conducted with the construction planning and management experts across the country. Thematic analysis of the responses indicated nine conceptual themes related to managing buffers in construction projects. The indicated themes give an overall picture of the prevailing features of ongoing buffer management processes in the industry. The results of the study pave the road for designing the next development steps to accommodate shifting from the standard buffer management practices to the lean ideal.
\end{abstract}

\section{KEYWORDS}

Lean construction, buffer management, prevailing features, scheduling

\section{INTRODUCTION}

Lean construction ventures three key strategies to enhance the construction performance being stabilization of workflow, reduction of inflow variation, and improvement of downstream performance. (Ballard and Howell 1994; Howell and Ballard 1994; Ballard and Howell 1997). The performance of the systems is profoundly bonded to their ability to cope with variations (Hopp and Spearman 2008). Variations are known to be an inherent component of the production systems (Shewhart 1939; Garvin 1988; Koskela 2000). They can be disseminated from one production unit to another. As a result, a production unit with a variable performance can destabilize the performance of the whole system (Thomas et al. 2002). Buffers in the form of extra capacity, time, or inventory can

1 Lecturer, Built Envir. Engrg. Dept., Auckland University of Technology, Auckland, New Zealand, mani.poshdar@aut.ac.nz

2 Senior lecturer, Civil and Envir. Engrg. Dept., Univ. of Acukland, New Zealand, v.gonzalez@auckland.ac.nz

3 Const. Mgmt. Graduate, Civil and Envir. Engrg. Dept., Univ. of Acukland, New Zealand, kbal263@aucklanduni.ac.nz 
protect the production unit against variations in its environment while preventing dissemination of variation to the environment (Hopp and Spearman 2008). Buffers compensate for the uncertainty in the actual rates of consumption and supply to each production unit, compensate for the variable average rates of consumption and supply between the units, and capacitate the project of a re-arrangement of work sequences within supplier and succeeding production units (Ballard and Howell 1994). The absence of buffers induces inefficiencies, deteriorates productivity, increases cycle times and inflates project cost (Howell and Ballard 1994; Tommelein et al. 1999; Poshdar et al. 2016; Poshdar et al. 2018). Thus, from a practical standpoint, without the use of buffers, a production system can hardly have efficient throughput (Hall 1983; Ballard 2000; Womack and Jones 2003; González et al. 2009; Erdmann et al. 2012). Despite the benefits of using buffers, they represent non-value-adding components of systems. Accordingly, lean ideal suggests avoiding the use of buffers to the maximum possible extent (Hopp and Spearman 2008). Therefore, projects are obliged to adopt a definite buffer management strategy that can simultaneously address the practical requirements and the lean ideal.

Despite all the advancement in developing buffer management techniques, the construction industry acknowledges the use of informal and intuitive approaches for buffer management (González and Alarcón 2010; González et al. 2013; Poshdar et al. 2015).In order to find a balance between theoretical goals and the practical norms regarding buffer management, this research was formulated to answer the three following main questions within the New Zealand construction industry: 1. what are the approaches used for buffer management? 2. What are the main challenges? And 3. How to promote tools that support buffer management?

\section{THE DEVELOPMENTS IN BUFFER MANAGEMENT}

Some of the prominent methods involved the use of buffers in projects over the past half century are as follows (Poshdar et al. 2016):

Program Evaluation and Review Technique (PERT) by Malcolm et al. (1959); it was one of the first scheduling methods that proposed a stochastic approach to calculate time contingencies.

Critical Chain Project Management (CCPM) by Goldratt (1997), which shifted the concern in the use of buffers from task protection to the protection of the project completion time.

The risk aggregation technique using theRoot Square Error (RSE) proposed by Newbold (1998), which presented a technique to calculate the size of buffers by aggregating the risks along different chains on a network of activities.

Normality assumption for the project completion time based on the Central Limit Theorem (CLT) suggested by Demeulemeester and Herroelen (2002), which uses statistical theory to estimate a proper size of buffers. It states that given a sufficiently large sample of a population, the mean of all samples from the same population will be approximately equal to the mean of the population. This mean value can be used to calculate the required size of buffers 
The reliability and stability buffering approach by Lee et al. (2006), which is developed based on the overlapping principle of activities, and the dynamic planning and control methodology (DPM).

The adaptive methods by Tukel et al. (2006) that consider the effects of resource tightness and number of precedence activities on the buffer allocation.

Computer-based methods such as in Koh (2006), Srisuwanrat and Ioannou (2007), and González and Alarcón (2010), which typically utilizea Monte Carlo approach.

\section{RESEARCH METHOD}

A systematizing expert interview was undertaken to obtain complete information from the participants by using spontaneous communications. This type of interviews focuses on knowledge of action and experience derived from practice (Bogner et al. 2009). Accordingly, twelve semi-structured face-to-face interviews were conducted with the industry professionals, which collected qualitative data on the active state of buffer management in construction sector across the country. The responses from the interviewees were transcribed and developed into coherent essays suitable for thematic analysis. The analysis results provide an insight into the operational condition of buffer management in construction projects, which is of particular importance for designing further steps to advance from the conventional management practices to the lean construction concept.

\section{DATA COLLECTION}

The semi-structured interviews that were adopted by this study represent a subjective data collection method. It solicits the interviewees with a series of pre-determined open-ended questions. This approach enables the research participants to elaborate on self-selected aspects of the questions (Lewis et al. 2007).

\section{SAMPLING}

A purposive sampling approach was carried out. The purposive sampling represents a non-probability technique, which enabled shifting the aim of sampling from generalizations to assessing particular features of the population. A specific type of sampling approach was undertaken that is known as expert sampling. Accordingly, the original population frame of the study was defined as the individuals who possess particular expertise in the field of buffer management in construction. The information contributed by the experts is representative of their full understanding of the area of expertise. Accordingly, qualified answers were providedto the study questions (Teddlie and Yu 2007; Tongco 2007; Magrath 2012). The information collected by interviewing experts can serve as a robust source for the analysts independent of the sampling size (Tongco 2007; Magrath 2012).

In order toensure that the interviewees would possess the expected expertise and full understanding of the area under investigation, the suggestion of Walton (2010)was adopted to outline the following sample selection criteria: 
Criterion 1: Having broad knowledge and understanding of construction management practices

Criterion 2: Having recent/on-going and direct involvement in construction planning

Criterion 3: Having the experience of allocating buffers to construction projects.

Twelve experts were selected (Table 1), whoprovided a strong diversity in their positions in relation to implementing the buffer management.

Table 1: Interviewees - Brief Description

\begin{tabular}{|c|c|c|c|c|c|}
\hline \# & $\begin{array}{c}\text { Years of } \\
\text { Experience }\end{array}$ & $\begin{array}{l}\text { Position } \\
\text { Held }\end{array}$ & \# & $\begin{array}{c}\text { Years of } \\
\text { Experience }\end{array}$ & $\begin{array}{l}\text { Position } \\
\text { Held }\end{array}$ \\
\hline Interviewee 1 & 12 & $\begin{array}{l}\text { Planner/Delay } \\
\text { Analyst }\end{array}$ & Interviewee 7 & 5 & $\begin{array}{l}\text { Project } \\
\text { Manager }\end{array}$ \\
\hline Interviewee 2 & 25 & Site Manager & Interviewee 8 & 10 & $\begin{array}{c}\text { Site } \\
\text { Manager }\end{array}$ \\
\hline Interviewee 3 & 15 & $\begin{array}{l}\text { Construction } \\
\text { Manager }\end{array}$ & Interviewee 9 & 9 & $\begin{array}{c}\text { Managing } \\
\text { Director }\end{array}$ \\
\hline Interviewee 4 & 30 & $\begin{array}{l}\text { Managing } \\
\text { Director }\end{array}$ & Interviewee 10 & 23 & $\begin{array}{l}\text { Senior } \\
\text { Planner }\end{array}$ \\
\hline Interviewee 5 & 40 & CEO & Interviewee 11 & 7 & $\begin{array}{l}\text { VDC/BIM } \\
\text { Manager }\end{array}$ \\
\hline Interviewee 6 & 15 & $\begin{array}{l}\text { Project } \\
\text { Manager }\end{array}$ & Interviewee 12 & 13 & $\begin{array}{l}\text { Project } \\
\text { Manager }\end{array}$ \\
\hline
\end{tabular}

\section{INTERVIEW SESSION}

The data collection process proceeded with conducting face-to-face interviews. Meeting the interviewee in person created an opportunity to have an in-depth understanding of perspectives of the participants. It also provided the opportunity to clarify the responses instantaneously. Each session was designed to take place in approximately one hour. The responses were recorded, given that the interviewees were permitted to stop the recording whenever amid the session. The discussions during the interview involved the necessity of using buffers in projects and the potential buffer management methods that couldbe obtained. The audio recordings of the interviews were transcribed carefully. The interviewee was given the opportunity to review the transcribed statements and request for excluding any part. 


\section{INTERVIEW QUESTIONS}

The interview protocol included three questions as follows, which conform to the main research questions.

1. What considerations are typical on variations in the performance of construction activities? 2. What are the methods used for the buffer management purposes?3. What are the main challenges in the current buffer management tools and process?

Three subject matter experts reviewed the questions to make sure the interviewees would have no problem in understanding the questions.

\section{THE THEMATIC ANALYSIS}

The steps of a thematic analysis proposed by Braun and Clarke (2006) were employed to decode and clarify the information provided by the interviewees. The analysis involved seven stages including transcription and review; generating initial codes; searching for the recurring pattern across the dataset; joining the found patterns against each other as well as against the original data; defining and naming themes, and producing the final report. Accordingly, nine following themes were identified and included inthe final report.

\section{PROJECTS REALIZE THE USE OF BUFFERS AS AN INEVITABLE COMPONENT}

Buffers are being used as an auxiliary component of the projects that keeps the job up and running. Figure reports the main reasons expressed by the twelve interviewees for using buffers.

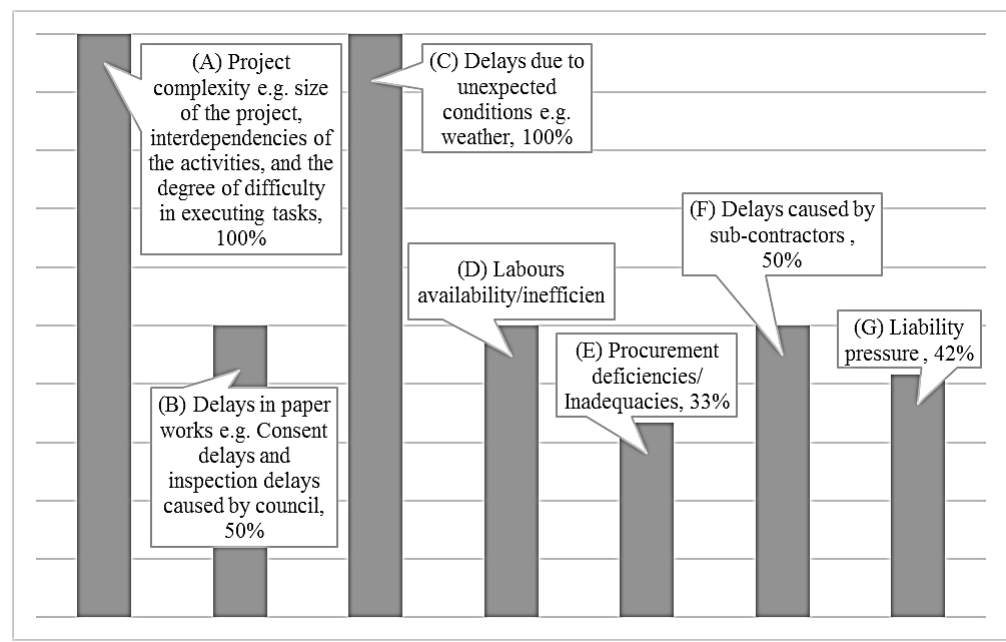

Figure 1: Main Reasons for using buffers as an inevitable component in projects. The percentage is based on the frequency of the reason being stated. no buffer management method with a holistic view is pursued

Eleven interviewees out of twelve (1-4 \& 6-12) were using the Critical Path Method $(\mathrm{CPM})$ as their main scheduling technique. Critical path refers to a sequence of 
networked operations that dictates the project completion time (Kelley Jr and Walker 1959). This method, however, is known for being unable to provide a holistic view of the operational situation of the project network. During the execution, the critical path may change frequently having some prolonged operations on the non-critical paths (Adlakha and Kulkarni 1989). It will restrain the applicability of the original project analysis results. Therefore, even though a considerable time is spent in the developing schedules, significant time overruns might be reported.

\section{NO SYSTEMATIC STRATEGY IS EMPLOYED TO ALLOCATE BUFFERS}

As a common approach, buffers are being incorporated to the projects' schedule by adding a fixed percentage of the expected duration to every operation on the project network (Interviewees 4, 5, 7, 8, 10 and 12). The percentage to be added to the duration is typically decided based on the personal judgment and experience of the project decision makers (Interviewees 4 and 10).

\section{THE CURRENT BUFFER MANAGEMENT METHODS ARE NOT EFFECTIVE}

Despite recognizing the use of buffers as an inevitable component, the interviews reinforced the fact that the projects are still plagued with delays. Particularly, the time allocation process to the sub-contractors and the materials suppliers is an arduous practice due to the large uncertainty (Interviewees 5, 7, 8 and 12). The buffer management methods in used by the projects can mitigate the time overruns only to a limited extent. The residual time overruns result in substantially inflated costs (Interviewees 4, 5, 7 and 12). These extra costs arise from involving labors and machinery in excess to compensate for the time deviations. Such ineffectiveness also extends over other projects by restraining the availability of the workforce (Interviewees 4).

\section{THE FINANCIAL PENALTIES ARE THE REAL DRIVERS}

In case of delays, the construction firms will end up with paying significant penalties (Interviewees 5, 7, 8 and 12). Any change of the program at the project execution phase will involve a full update of the scheduled resources. Construction projects are resource intensive. Therefore, the rescheduling of the resources is associated with substantial extra costs (Interviewees 5, 8 and 12). The avoidance of such cost surcharges pressurizes the contractors to complete the tasks even at the cost of a deteriorated quality (Interviewees 5, 7, 8 and 12). This finding sits well with the observations of Goldratt et al. (1992)who associated the ultimate goal of every enterprise with making money.

\section{THE CONTRACTUAL ISSUES MAY CURTAIL THE USE OF BUFFER}

In line with the previous finding, the analysis of the responses indicated another aspect of the moneymaking mindset of the construction enterprises that affects the use of buffer management strategies. In the common types of contractual agreements such as the fixedprice contracts, the contractors are prevented from being benefited by the potential savings incurred due to improvements in their production performance. It has abstained the use of efficient buffer management strategies (Interviewee 7). 


\section{NEW BUFFER MANAGEMENT TECHNOLOGIES ARE RESISTED}

Disbelief in alleviating the construction scheduling problems by using new technologies was observed. Twenty-five percent of the respondents expressed their reluctance towards implementing new technology for the buffer management purposes (Interviewees 2, 8 and 12). They placed less credence in the benefits to be gained from adopting new technology. As a result, they stated a preference towards non-computerized methods. Interviewee 12 demonstrated a tendency towards spending the extra money to hire more experienced professionals instead of employing new technology.

\section{CURRENT BUFFER MANAGEMENT TOOLS AND TECHNIQUES ARE CHALLENGING}

The challenges that were identified in utilizing the buffer management tools and techniques can be divided into the following three broad categories:

Challenges at the organizational level:Lack of the experienced construction planner/programmer (Interviewees 2, 9 and 10); Lack of training among the professionals to use a particular method (Interviewees 9 and 10); Organizational structure (Interviewees 7, 10 and 11); Lack of collaboration between the stakeholders at the planning phase (Interviewees 3, 9 and 10); Partial/late implementation of buffering strategy (Interviewees 3, 9 and 10).

Challenges at the individual level:A lack of understanding of the new complex methodologies (Interviewees 1 and 2); Lack of knowledge about the benefits of using optimum buffers in project schedules (Interviewees 2 and 8); Lack of commitment (Interviewees 1, 2 and 12); Being inexperienced with the buffering strategies (Interviewees 2, 3, 8 and 12)

Challenges in using the available tools:Lengthy procedure to allocate the buffers (Interviewees 4, 8 and 12); Complexity of the tools, which typically need to be operated by trained and specialized personnel; A prolonged learning process that has been found to be a key discouraging feature (Interviewee 2, 3, 5 and 8); The restricted information provided by the typical software packages, which remain limited to the activity schedules, resource and assignment lists. For robust decision-making, however, they should be able to involve multiple other facets of the project. It means the users would be urged to combine several software packages to track and control the project activities (Interviewee 2, 4 and 6); the typical software packages such as MS Project allow only limited number of baseline schedules, which make the scheduling process extremely onerous in the event of more changes to the project (Interviewee 10).

\section{THE MAIN FEATURES THAT CAN PROMOTE THE USE OF A BUFFER MANAGEMENT TOOL}

As discussed, the popular tools that could support buffer management have been found to be far from gaining wide acceptance in construction projects. Three main feature were indicated by the interviewee, which could promote the application of a certain buffer 
management tool. Automation in the application:A computerized tool with a simple, user-friendly interface that facilitates generating construction program by personnel with minimum computer knowledge was recognized as a key enabler of buffer management in construction projects (Interviewee 2, 3, 5, 8, 9 and 12). It was suggested that the human interactions should be reduced to the greatest possible extent in an ideal tool (Interviewee 4). Customizing ability: Having a mechanism involved in interacting with the users and enabling them to exchange information with the tool wasfound crucial to the acceptance of the tool (Interviewee 4, 6 and 12). Visual presentation: The visualizations can be used as a communication means during the planning processes. For instance, showing cost variations by the project duration helps to enhance the robustness of decisions (Interviewee 4, 10 and 11).

Table 2 summarizes the contributions of the interviewees to the detected themes.

Table 2: Summary of contributions

\begin{tabular}{cccc}
\hline Theme & $\begin{array}{c}\text { Interviewees whose opinion } \\
\text { contributed to the theme }\end{array}$ & Theme & $\begin{array}{c}\text { Interviewees whose opinion } \\
\text { contributed to the theme }\end{array}$ \\
\hline 1 & 1 to 12 & 6 & 7 \\
2 & 1 to 4 , and 6 to 12 & 7 & 2,8 and 12 \\
3 & $4,5,7,8,10$ and 12 & 8 & 1 to 6,8 to 10 and 12 \\
4 & $4,5,7,8$ and 12 & 9 & 2 to 6,8 to 11 and 12 \\
5 & $5,7,8$ and 12 & & \\
\hline
\end{tabular}

\section{CONCLUSIONS}

While buffers are known as the non-value-adding components of the projects in lean construction, their absence can make the construction program vulnerable to disruptions. Such paradoxical situation calls for the implementation of a cohesive buffer management strategy in projects that enable optimum use of buffers. This paper provided an insight into the operational conditions of buffer management strategies in construction projects by conducting an interview-based study in New Zealand. Twelve industry experts were chosen systematically and invited for a face-to-face interview. The thematic analysis of the responses indicated nine main themes representative of the experts' opinion about the status of buffer management methods in construction projects, the challenges, and opportunities to implement an enhanced buffer management approach.

Even though therespondents recognized the use of buffer as an inevitable component of their projects, it was found that buffers were being incorporatedinto the project program as a fixed percentage added to the expected duration of each operation. The majority of the respondents were relying on CPM as their main scheduling method. However, this method has proven to be unable in providing a holistic view of the potential operational status of the project network. The lack of a method that could provide this holistic view of the project network was one of the main challenges identified by the experts in dealing with buffer management. As a result, the projects still deal with time overruns that could cause substantial financial penalties for the 
construction firms. The firms may try to minimize these financial penalties by reducing the quality of work. Additional issues, such as the fixed-price agreements, which are typical to construction projects has been found discouraging the adoption of an enhanced buffer management strategy. Despite the resistance from the construction professionals in changing their buffer management routines, the experts indicated that automation, customizingability and involvement of visual presentation could be the three fundamental features to promote the use of a new buffer management approach. These findings suggest that in order to establish a balance between the lean theoretical goals and the practical norms in buffer management domain, a method must be established that could indicate the theoretical optimum allocation of buffer, while supports a holistic view of the project. The method should be included by customizing features to incorporate the specific requirements of any particular project. The implementation of this method in an automated tool with the ability to provide a visual presentation of the buffering solution can promote its function in the construction projects. The studymainly focused on New Zealand construction environment, where the majority of firms are of a small to medium sizes with the number of employees fewer than 50. Further studies are required to elucidate the applicability of the results to the projects undertaken by firms with larger sizes.

\section{REFERENCES}

Adlakha, V. G., and Kulkarni, V. G. (1989). "A CLASSIFIED BIBLIOGRAPHY OF RESEARCH ON STOCHASTIC PERT NETWORKS-1966-1987." Infor, 27(3), 272296.

Ballard, G., and Howell, G. (1994). "Implementing lean construction: stabilizing workflow." Proc., the 2nd Annual Conference of International Group for Lean Construction, 105-114.

Ballard, G., and Howell, G. (1997). "Implementing lean construction: improving downstream performance." Lean construction, L. Alarcón, ed., A.A. Balkema Publishers, Rotterdam, Netherlands, 111-125.

Ballard, H. G. (2000). "The last planner system of production control." Ph.D., the University of Birmingham, Birmingham, UK.

Bogner, A., Littig, B., and Menz, W. (2009). Interviewing experts, Palgrave Macmillan Basingstoke, England.

Braun, V., and Clarke, V. (2006). "Using thematic analysis in psychology." Qualitative research in psychology, 3(2), 77-101.

Demeulemeester, E. L., and Herroelen, W. (2002). Project scheduling: a research handbook, Kluwer Academic Publishers, Boston, USA.

Erdmann, T. P., Boessenkool, H., Hogewoning, L., and Does, R. J. M. M. (2012). "Quality Quandaries: Reducing Work in Process at an Emergency Assistance Center." Quality Engineering, 25(1), 78-84.

Garvin, D. A. (1988). Managing quality: The strategic and competitive edge, Free Press, New York.

Goldratt, E. M. (1997). Critical Chain, The North River Press Great Barrington, MA. 
Goldratt, E. M., Cox, J., and Whitford, D. (1992). The goal: a process of ongoing improvement, North River Press.

González, V., and Alarcón, L. F. (2010). Uncertainty Management in Repetitive Projects Using WIP Buffers, Lambert Academic Publishing, Germany.

González, V., Alarcón, L. F., and Molenaar, K. (2009). "Multiobjective design of WorkIn-Process buffer for scheduling repetitive building projects." Automation in Construction, 18(2), 95-108.

González, V., Alarcón, L. F., and Yiu, T. W. (2013). "Integrated methodology to design and manage work-in-process buffers in repetitive building projects." Journal of the Operational Research Society 64(8), 1182-1193.

Hall, R. W. (1983). Zero Inventories Homewood, Dow Jones-Irwin, Homewood, Illinois, USA.

Hopp, W. J., and Spearman, M. L. (2008). Factory Physics, McGraw-Hill, New York, USA.

Howell, G., and Ballard, G. (1994). "Implementing lean construction: reducing inflow variation." Lean construction.

Kelley Jr, J. E., and Walker, M. R. "Critical-path planning and scheduling." Proc., Eastern joint IRE-AIEE-ACM computer conference, ACM, 160-173.

Koh, C. H. "Buffer Evaluation for Demand Variability using Fuzzy Logic." Proc., 14th Annual Conference of International Group for Lean Construction.

Koskela, L. (2000). "An exploration towards a production theory and its application to construction " Ph.D., Technical Research Centre of Finland, Espoo, Finland.

Lee, S., Peña-Mora, F., and Park, M. (2006). "Reliability and stability buffering approach: Focusing on the issues of errors and changes in concurrent design and construction projects." Journal of Construction Engineering and Management, 132(5), 452-464.

Lewis, P., Thornhill, A., and Saunders, M. (2007). Research methods for business students, Pearson Education UK.

Magrath, V. (2012). "An exploration of eating distress and traumatic experiences in women and the effectiveness of dialectical behaviour therapy." the University of Warwick.

Malcolm, D. G., Roseboom, J. H., Clark, C. E., and Fazar, W. (1959). "Application of a technique for research and development program evaluation." Operations Research, 7(5), 646-669.

Newbold, R. C. (1998). Project management in the fast lane: Applying the Theory of Constraints, CRC Press, Boca Raton, Florida, USA.

Poshdar, M., González, V., Raftery, G., Orozco, F., Romeo, J., and Forcael, E. (2016). "A Probabilistic-Based Method to Determine Optimum Size of Project Buffer in Construction Schedules." Journal of Construction Engineering and Management, 142(10).

Poshdar, M., González, V. A., and Belayutham, S. (2015). "An Inclusive Probabilistic Buffer Allocation Method." 23rd Annual Conference of the International Group for Lean ConstructionPerth, Australia.

Poshdar, M., González, V. A., Raftery, G. M., Orozco, F., and Cabrera-Guerrero, G. G. (2018). "A multi-objective probabilistic-based method to determine optimum 
allocation of time buffer in construction schedules." Automation in Construction, 92, 46-58.

Shewhart, W. A. (1939). Statistical Method from the Viewpoint of Quality Control, Van Nostrand, Princeton, New Jersey, USA.

Srisuwanrat, C., and Ioannou, P. G. "Optimal scheduling of probabilistic repetitive projects using completed unit and genetic algorithms." Proc., Winter 2007 Simulation Conference, IEEE Press, 2151-2158.

Teddlie, C., and Yu, F. (2007). "Mixed methods sampling a typology with examples." Journal of mixed methods research, 1(1), 77-100

Thomas, H., Horman, M., de Souza, U., and Zavřski, I. (2002). "Reducing Variability to Improve Performance as a Lean Construction Principle." Journal of Construction Engineering and Management, 128(2), 144-154.

Tommelein, I. D., Riley, D. R., and Howell, G. A. (1999). "PARADE GAME: IMPACT OF WORK FLOW VARIABILITY ON TRADE PERFORMANCE." ASCE, $J$. Constr. Eng. Manage., 125(5), 304-310.

Tongco, M. D. C. (2007). "Purposive sampling as a tool for informant selection." Ethnobotany Research and Applications, 5(1), 147-158.

Tukel, O. I., Rom, W. O., and Eksioglu, S. D. (2006). "An investigation of buffer sizing techniques in critical chain scheduling." European Journal of Operational Research, 172(2), 401-416.

Walton, D. (2010). Appeal to expert opinion: Arguments from authority, Penn State Press. Womack, J. P., and Jones, D. T. (2003). Lean thinking: banish waste and create wealth in your corporation, revised and updated, Palgrave Macmillan UK, New York, USA. 